\title{
2 Responses of two Mediterranean seagrasses to experimental changes in salinity
}

\author{
4 Yolanda Fernández-Torquemada • \\ 5 José Luis Sánchez-Lizaso
}

6 Received: 27 October 2010/Revised: 7 February 2011/ Accepted: 12 February 2011

7 (C) Springer Science+Business Media B.V. 2011

8 Abstract The aim of this study is to examine the 9 effects of variations in salinity levels on growth and survival of two fast-growing Mediterranean seagrasses, Cymodocea nodosa and Zostera noltii. We also tested the capacity of $C$. nodosa to acclimate to a gradual increase in salinity and to discover how it responds to a sharp rise in salinity in combination with other factors, such as increases in temperature, seasonality and different plant-population origins. Several short-term (10 days) experiments were conducted under controlled conditions. For each experiment, ten marked shoots were placed in 5-1 aquaria, where they were exposed to different salinity treatments (ranging from 2 to $72 \mathrm{psu}$ ). Growth and survival of both species were significantly affected by salinity. A significant effect between salinity and temperature on the shoot growth rate of $C$. nodosa was also detected, but not on shoot mortality. When C. nodosa plants were acclimated by gradually increasing the salinity level, it was observed that acclimatisation improved tolerance to salinity changes. A different response to salinity variations, depending on the origin of the plants or the season of

\section{Handling editor: Pierluigi Viaroli}

Y. Fernández-Torquemada $(\bowtie) \cdot$ J. L. Sánchez-Lizaso Department of Marine Sciences and Applied Biology, University of Alicante, P.O. Box 99, 03080 Alicante, Spain

e-mail: Yolanda.Fernandez@ua.es the year, was also detected. These results indicated that Z. noltii plants tolerate conditions of hyposalinity better than $C$. nodosa, and that the tolerance range of C. nodosa may change depending on the temperature, the season or the population.

Keywords Salinity effects - Salinity tolerance · 36 Desalination impact . Cymodocea nodosa.

Zostera noltii

\section{Introduction}

Seagrasses have evolved from continental angiosperms that have returned and adapted to life in completely submerged saline environments (den Hartog, 1970), which they are able to tolerate as a result of various biochemical, physiological and morphological adaptations (Jagels, 1973; Tyerman, 1989; Arai et al., 1991; Pak et al., 1995; Fukuhara et al., 1996; Fernández et al., 1999; Touchette, 2007). These mechanisms have allowed seagrasses to occur naturally in various aquatic environments with different salinity values, including brackish and oceanic waters (Walker, 1985; Adams \& Bate, 1994; Tomasko \& Hall, 1999), and from almost stable to a more fluctuating environment.

To date, studies examining salinity influence or tolerance in seagrasses have focused mainly on estuarine species, which can be exposed to a wide range of salinity levels, due to seasonal and natural

\begin{tabular}{|l|lll|}
\hline & Journal : Medium 10750 & Dispatch : 25-3-2011 & Pages : 13 \\
Article No. : $\mathbf{6 4 4}$ & $\square$ LE & $\square$ TYPESET \\
MS Code : HYDR5743 & $\checkmark$ CP & $\checkmark$ DISK \\
\hline
\end{tabular}


variations occurring in their habitat (Wortmann et al., 1997; Benjamin et al., 1999; Kamermans et al., 1999). Results from these studies have shown that alterations to salinity levels can affect plant metabolism, growth, reproduction, survival and distribution (McMillan \& Moseley, 1967; Zieman, 1975; Walker \& McComb, 1990; Montague \& Ley, 1993; Hillman et al., 1995; Ramage \& Schiel, 1998; Vermaat et al., 2000; Chesnes \& Montague, 2001). However, in marine environments, salinity is considered an approximately constant factor, so any alteration to salinity levels may lead to significant disturbances to open water seagrasses that are more stenohaline species. Salinity values in the Mediterranean Sea are not naturally subjected to large and rapid fluctuations. However, some Mediterranean coastal areas are currently exposed to anthropogenic alterations in salinity levels caused by the discharge of brine effluents from desalination plants (Fernández-Torquemada et al., 2005a, 2009; Gacia et al., 2007). These brine discharges have high salinity levels (40-70 psu), and sometimes a relatively high temperature and low pH (Lattemann \& Höpner, 2003), so these and other environmental conditions occurring at the same time may have an interaction with increased salinity levels.

Previous studies have shown that the endemic species Posidonia oceanica is quite sensitive to increases in salinity levels (Fernández-Torquemada \& Sánchez-Lizaso, 2005; Gacia et al., 2007; SánchezLizaso et al., 2008), but little information exists with regard to the response and tolerance of other Mediterranean seagrasses, such as Cymodocea nodosa and Zostera noltii. C. nodosa and Z. noltii are relatively small and fast-growing seagrasses with similar behaviour and ecology, but different geographical distribution. Whereas $C$. nodosa is a common species in the Mediterranean and the eastern Atlantic, from south Portugal to Senegal and around the Canary Islands (den Hartog, 1970), Z. noltii is widespread along the European Atlantic coastline from Sweden to Mauritania, but is not common in the Mediterranean Sea. C. nodosa may also show a wider depth distribution (ranging from the intertidal to $33-35 \mathrm{~m}$ deep) than $Z$. noltii, which has a narrower vertical distribution (Drew, 1978; Vermaat et al., 1993; Reyes et al., 1995). On the other hand, both species have a high tolerance to a variety of environmental conditions, such as irradiance changes, seasonal temperature fluctuations and different nutrient concentrations (Phillips \& Meñez, 1988; Marbà et al., 1996), and can become established on a wide range of substrata, from sandy to muddy pristine as well as degraded coastal sites (Peduzzi \& Vukovič, 1990; Pavón-Salas et al., 2000; Charpentier et al., 2005). As the habitat preferences and environmental limits of $C$. nodosa and Z. noltii are very broad, these species can be expected to have higher salinity tolerance levels than $P$. oceanica. Throughout their distribution, both seagrasses can be found forming mixed meadows in areas where salinity values differ from marine conditions, such as estuaries and coastal lagoons (den Hartog, 1970; Mazzella et al., 1993; Vermaat et al., 2000; Greve \& Binzer, 2004). Based on their field distribution, C. nodosa and Z. noltii have been classified as euryhaline species (den Hartog, 1970), although it is expected that individuals of both species that currently occur in coastal Mediterranean waters will have a different salinity tolerance to those from other populations occurring in habitats with greater fluctuations in salinity.

On the other hand, salinity tolerance in both species cannot be easily inferred from these field data, as the salinity range of normal growth and development for a species is usually narrower than its real tolerance limits (Kinne, 1964), and there can be multiple stressors in the field affecting the behaviour and distribution of a species. As a result, controlled experimental studies are needed to gather significant information about the environmental tolerance of a species. There are some experimental studies that refer to the effects of salinity variations on these seagrasses (Caye \& Meinesz, 1986; Hootsmans et al., 1987; Loques et al., 1990; Caye et al., 1992; Vermaat et al., 2000; Pagès et al., 2010). Most of these studies have focused on the role that reduced salinity levels play in seed germination. Caye \& Meinesz (1986) demonstrated that they could induce $C$. nodosa seed germination at any time of the year by reducing the salinity and using a temperature between 20 and $25^{\circ} \mathrm{C}$. These same authors observed that seeds generally do not germinate at a salinity level of 38 psu, and the few that germinated did so very slowly (over months). Furthermore, seedlings that had germinated at lower salinity levels (15-30 psu) were the only ones that continued to develop. Other studies have demonstrated that low salinity levels also stimulate Z. noltii seed germination (Hootsmans

\begin{tabular}{l|lll|} 
Journal : Medium 10750 & Dispatch : 25-3-2011 & Pages : 13 \\
Article No. : $\mathbf{6 4 4}$ & $\square$ LE & $\square$ TYPESET \\
MS Code : HYDR5743 & CP $_{\text {DISK }}$ \\
\hline
\end{tabular}


et al., 1987; Loques et al., 1990). Vermaat et al. (2000) carried out an experiment with adult $Z$. noltii plants from two separate populations that were exposed to 15 and 35 psu and the day-length regimes of two seasons, and observed that both populations suffered high mortality at $35 \mathrm{psu}$. In a recent paper, Pagès et al., (2010) estimated that $C$. nodosa was tolerant to moderate salinity increases ( $44 \mathrm{psu}$ ), while apparently only sub-lethal effects appeared at 54 psu, but they only studied four salinity treatments.

The first aim of the present study is to redress the lack of existing information on the tolerance of Cymodocea nodosa and Zostera noltii to salinity changes and to establish their possible range of salinity tolerance. Several experiments of a short duration (10 days) were conducted under controlled conditions to estimate shoot growth rate and survival in both species when exposed to different levels of salinity. A more thorough study of $C$. nodosa was also carried out to prove the effect of other factors associated with the discharge of desalination brine on this species. We thus tested the capacity of $C$. nodosa to acclimate to gradual increases in salinity and its response to sharp rises in salinity combined with other factors or conditions, such as temperature increases, seasonality and different plant populations.

\section{Materials and methods}

Plant material

Cymodocea nodosa and Zostera noltii shoots were carefully collected by scuba diving from a mixed shallow meadow $(-2 \mathrm{~m})$ at Almadraba Beach (Alicante, SE Spain). Plants of a similar size and vitality were transported to the laboratory in a cooler containing ambient seawater from the sampling site (average salinity of $37.5 \mathrm{psu}$ ). Once transferred to the laboratory, the shoots were marked using a modified Zieman method (1974) and placed in plastic 5-1 aquaria with sediment at different treatments for 10 days.

\section{Experimental design}

Six sets of experiments were conducted in aquaria under environmentally controlled conditions, with a daylight regime of $12 \mathrm{~h}$ of light and $12 \mathrm{~h}$ of darkness, and an average daytime underwater photon flux of $30 \mu \mathrm{mol}$ quanta $\mathrm{m}^{-2} \mathrm{~s}^{-1}$ (measured with a LiCor 193 SA spherical quantum sensor), that is approximately the environmental light intensity observed in the plants sampling site (Almadraba Beach, Alicante; $\left.38^{\circ} 22^{\prime} \mathrm{N}, 0^{\circ} 26^{\prime} \mathrm{W}\right)$. For each experiment, three aerated aquaria (replicates) were assigned per treatment. With the exception of experiment VI, ten plants were placed in each aquarium with no acclimation period, in order to simulate sudden increases in salinity. In all the experiments carried out, temperature and salinity were measured daily using a conductimeter (model 1230; Thermo Orion), and salinity values were adjusted when necessary. Control-treatment salinity was the level measured in the area where the plants were collected (with a range of 36.8-38.1 psu, and an average of $37.5 \mathrm{psu}$ ). Increased salinity treatments were similar to hypersalinity values associated with a desalination brine discharge (Fernández-Torquemada et al., 2005a, 2009) and were prepared by adding natural salt produced by Santa Pola saltworks from seawater concentrate to ambient coastal seawater, while lower salinities were obtained by diluting seawater with freshwater. Once the aquaria were filled with treatment water, they were placed in a larger water-filled container, to keep temperatures as constant as possible during each experiment.

Leaf growth was measured, by using a hypodermic needle for $C$. nodosa or by using a water-insoluble marking pen for $Z$. noltii, as a daily elongation rate $\left(\mathrm{cm}^{2}\right.$ shoot $^{-1}$ day $\left.^{-1}\right)$, and mortality as a percentage of dead shoots per aquaria at the end of each experiment. Shoots were considered dead when leaves died back and rhizomes and roots were totally degraded. In order to compare the results from selected experiments, some leaf growth rates were reported as a percentage relative to the growth obtained for the control plants.

The following section details the objectives, experimental design and methodology of the different experiments carried out.

\section{Experiment I: salinity tolerance of Zostera noltii}

To evaluate the effect of salinity on shoot growth rate and survival of $Z$. noltii, three consecutive and different tests of a short duration (10 days) were carried out during the summer period (July and August, temperature $\approx 25-27^{\circ} \mathrm{C}$ ), working with a

\begin{tabular}{l|lll|} 
Journal : Medium 10750 & Dispatch : 25-3-2011 & Pages : 13 \\
Article No. : $\mathbf{6 4 4}$ & $\square$ LE & $\square$ TYPESET \\
MS Code : HYDR5743 & $\checkmark$ CP & $\checkmark$ DISK \\
\hline
\end{tabular}


wide range of salinities (21 different treatments 248 between 2 and 72 psu, each one replicated in three 249 independent aquaria).

\section{Experiment II: salinity tolerance of Cymodocea nodosa}

This study was designed to evaluate the effect of different salinity levels on shoot growth rate and survival of $C$. nodosa. For this experiment, five shortterm (10 days) assays were carried out during spring and summer months (April-July, temperature $\approx 22-25^{\circ} \mathrm{C}$ ), with 27 different salinity levels ranging from 2 to 72 psu (each salinity treatment replicated in three aquaria).

\section{Experiment III: seasonal response of C. nodosa} to increases in salinity

The aim of this experiment was to detect a possible seasonal variation of the response by $C$. nodosa to hypersalinity (control, 42, 47 and $52 \mathrm{psu}$ ). Increased salinity experiments (10 days) were carried out at two different times of the year. Winter time (20-30 January, temperature $\approx 15^{\circ} \mathrm{C}$ ) was selected because of the reduced growth rate of $C$. nodosa during this season, compared with summer (5-15 July, temperature $\approx 25^{\circ} \mathrm{C}$ ), when, due to the accumulation of sucrose and starch and increases in irradiance and temperature, the species shows a higher rate of development.

\section{Experiment IV: salinity and temperature interaction} effects on C. nodosa

This experiment of 10 days was carried out to examine the synergistic effects of increases in temperature and salinity. Control aquaria were maintained at $20^{\circ} \mathrm{C}$ seawater temperature during that period (spring, March), while, for the other aquaria, a commercial heater was used with a thermostat to increase the temperature to $25^{\circ} \mathrm{C}$, representing summer temperatures in their natural environment. Within each temperature regime $\left(20\right.$ and $\left.25^{\circ} \mathrm{C}\right)$, four salinity treatments were tested to represent an increase in this variable: 37 (control), 43, 48 and 53 psu.
Experiment V: differences between Cymodocea nodosa populations

This experiment was performed during 10 days in August (temperature $\approx 27^{\circ} \mathrm{C}$ ) to determine whether the response of this species to changes in salinity can vary between individual plants from two populations adapted to different conditions. The survival rates and shoot growth rate among two $C$. nodosa populations were compared: one from the western Mediterranean Sea (Alicante; $38^{\circ} 22^{\prime} \mathrm{N}, 0^{\circ} 26^{\prime} \mathrm{W}$ ) and another from a near coastal lagoon located in southeast Spain (Mar Menor, Murcia; $37^{\circ} 48^{\prime} \mathrm{N}, 0^{\circ} 46^{\prime} \mathrm{W}$ ) with a higher salinity level (42-47 psu). The salinity levels applied were $37 \mathrm{psu}$ (the ambient level at the Mediterranean sampling site), $44 \mathrm{psu}$ (the level at the lagoon when and where the plants were collected), 47 and 50 psu.

Experiment VI: acclimation versus acute increases in C. nodosa

The aim of this experiment, also performed during August (temperature $\approx 26^{\circ} \mathrm{C}$ ), was to determine whether the acclimation of Cymodocea nodosa to gradual salinity variations allows for a greater tolerance to osmotic stress than an instantaneous transfer, as occurs with other seagrass species (Ralph, 1998). In some treatments, plants were acclimated in their respective aquaria to three different salinity levels $(42,47$, and 52 psu) in a stepwise manner ( 2.5 psu per day) up from the habitat salinity of 37 psu, reaching the maximum salinity after 2 (42 psu), 4 (47 psu) and 6 days (52 psu). In other treatments, plants were subjected to sudden increases in salinity (also 42, 47 and $52 \mathrm{psu}$ ), as performed in previous experiments. Finally, all plants were subjected to these salinity treatments during 10 days.

Statistical analyses

One-way ANOVA was used in experiments I and II to test for differences in mortality among the different salinity treatments used (including one as control). Nested ANOVA was used in the same experiments to test differences in shoot growth rate, with salinity considered as a fixed factor replicated in three aquaria (random factor and nested within salinity) and with ten marked shoots (replicates). In the rest of the experiments, an orthogonal factor was added

\begin{tabular}{l|lll|} 
Journal : Medium 10750 & Dispatch : 25-3-2011 & Pages : 13 \\
Article No. : 644 & $\square$ LE & $\square$ TYPESET \\
MS Code : HYDR5743 & $\checkmark$ CP & $\checkmark$ DISK \\
\hline
\end{tabular}




\section{Results}

(temperature, original population, seasonality or acclimation) to determine possible interactions between salinity and these factors. Homogeneity of variance had been previously verified using the Cochran test (Underwood, 1997). The data were log-transformed if normality was not verified.

When analysis of variance identified a significant difference for any factor, the multiple comparison post-hoc test SNK (Student-Newman-Keuls) was applied to determine specific treatment differences. All calculations were performed using the GMAV.5 program (University of Sydney; Underwood \& Chapman, 1997), with a minimum significance level established at $P<0.05$.

The growth and survival of Zostera noltii were both significantly affected by water salinity (Fig. 1). Shoot growth rate was considerably affected at higher salinities, but not at reduced salinities (Fig. 1). SNK test results revealed that elongation rates were similar
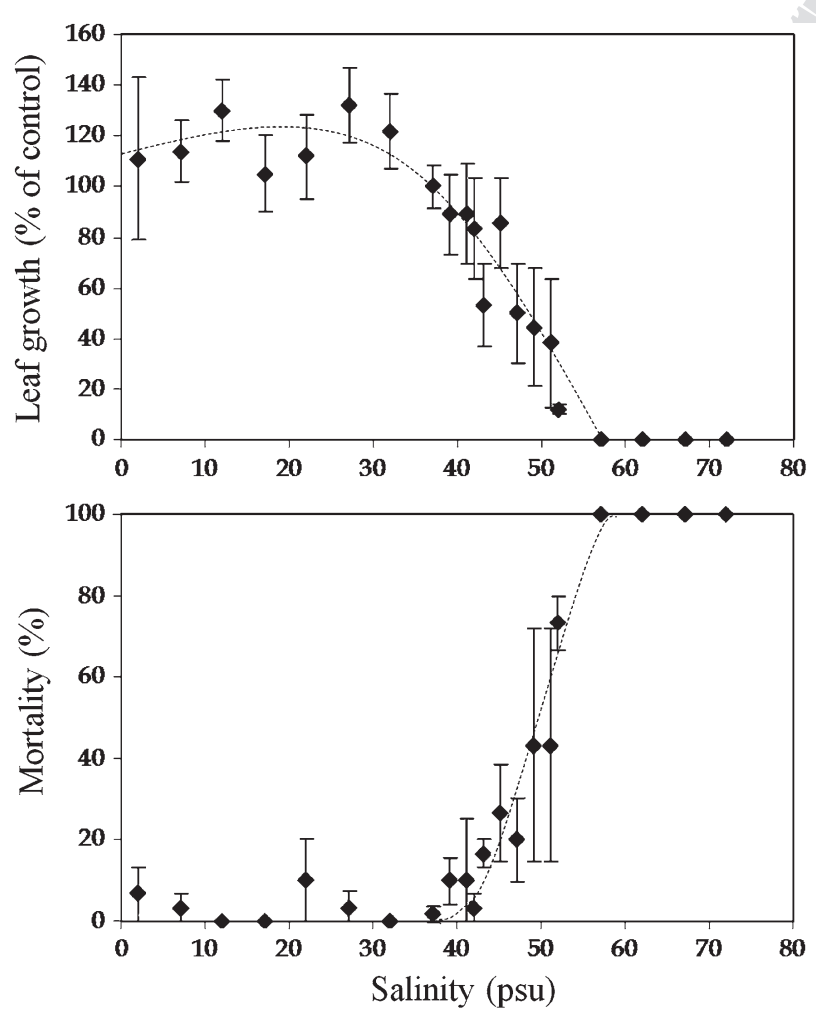

Fig. 1 Zostera noltii leaf growth (relative to the growth of the control plants) and mortality percentage at different salinity levels (bars represent standard errors) and maximal at 2-41 psu, decreasing significantly from 42 to $52 \mathrm{psu}(P<0.05)$. No growth was observed at 57 psu and higher. Hypersalinity also affected the mortality rate of this species (Fig. 1). $Z$. noltii plants sustained considerable mortality at salinity levels above 43 psu (>16.7\%), reaching $50 \%$ at $\sim 50$ psu and $100 \%$ mortality at 57 psu and higher.

Salinity also had a strong effect on leaf elongation rate and mortality in Cymodocea nodosa (Fig. 2). The relationship between shoot growth rate and salinity was bell-shaped (Fig. 2), with a distinct peak at 30-39 psu, and a significant reduction at salinity levels higher than 41 psu or lower than 16 psu. Mortality showed an opposite pattern (Fig. 2), with a minimum value at the control salinity level. Shoot mortality remained lower than $50 \%$ at salinity levels of less than $50 \mathrm{psu}$, but increased sharply above this level. All plants died when exposed to freshwater ( $0 \mathrm{psu})$ and to the highest salinity concentrations ( $\geq 57 \mathrm{psu}$ ).

The $C$. nodosa response to salinity increases during the two seasons studied (winter and summer) showed a significantly different behaviour (Fig. 3). The life
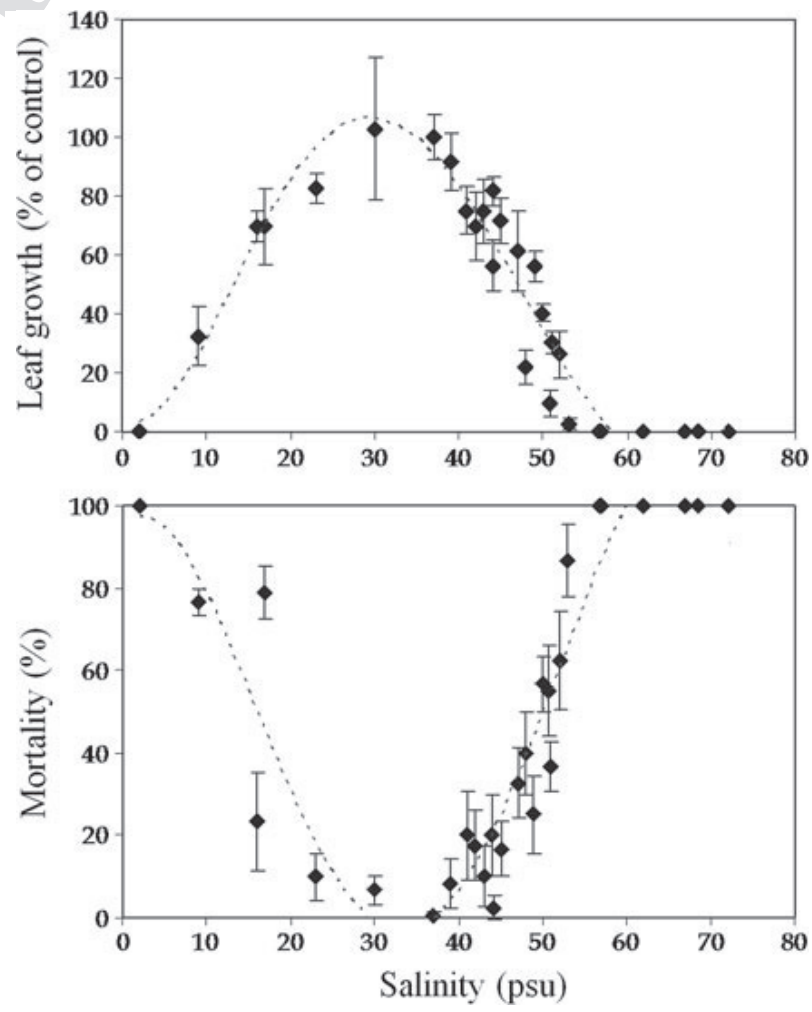

Fig. 2 Cymodocea nodosa leaf growth (relative to the growth of the control plants) and mortality percentage at different salinity levels (bars represent standard errors)

\begin{tabular}{|l|lll|}
\hline & Journal : Medium 10750 & Dispatch : 25-3-2011 & Pages : 13 \\
Article No. : 644 & $\square$ LE & $\square$ TYPESET \\
MS Code : HYDR5743 & $\vee_{\text {CP }}$ & $\checkmark$ DISK \\
\hline
\end{tabular}


cycle of this species is strongly marked by seasonality (Pérez \& Romero, 1992), with the result that in summer, the plants presented a significantly $(P<0.001)$ higher leaf growth $\left(0.1963 \mathrm{~cm}^{2}\right.$ day $^{-1}$ shoot $\left.^{-1}\right)$ than in winter $\left(0.0352 \mathrm{~cm}^{2}\right.$ day $^{-1}$ shoot $\left.^{-1}\right)$. To compare the data obtained from the two seasons, the results were expressed as a percentage relative to the growth obtained at the control treatment (Fig. 3). Here, twoway ANOVA showed a significant interaction between salinity and the season of the year in which the experiment was carried out (Table 1). Subsequent SNK post-hoc tests indicated that, in summer, $C$. nodosa shoot growth rate was significantly higher at the control salinity level than at the other salinity treatment levels, whereas in winter, higher salinity $(51 \mathrm{psu})$ is the only level that differs from the rest (Fig. 3). It was also observed that the effects of increased salinity on $C$. nodosa mortality was more evident in summer than in winter (Fig. 3), although no significant interaction was found between seasonality and salinity (Table 1). Shoot mortality was generally
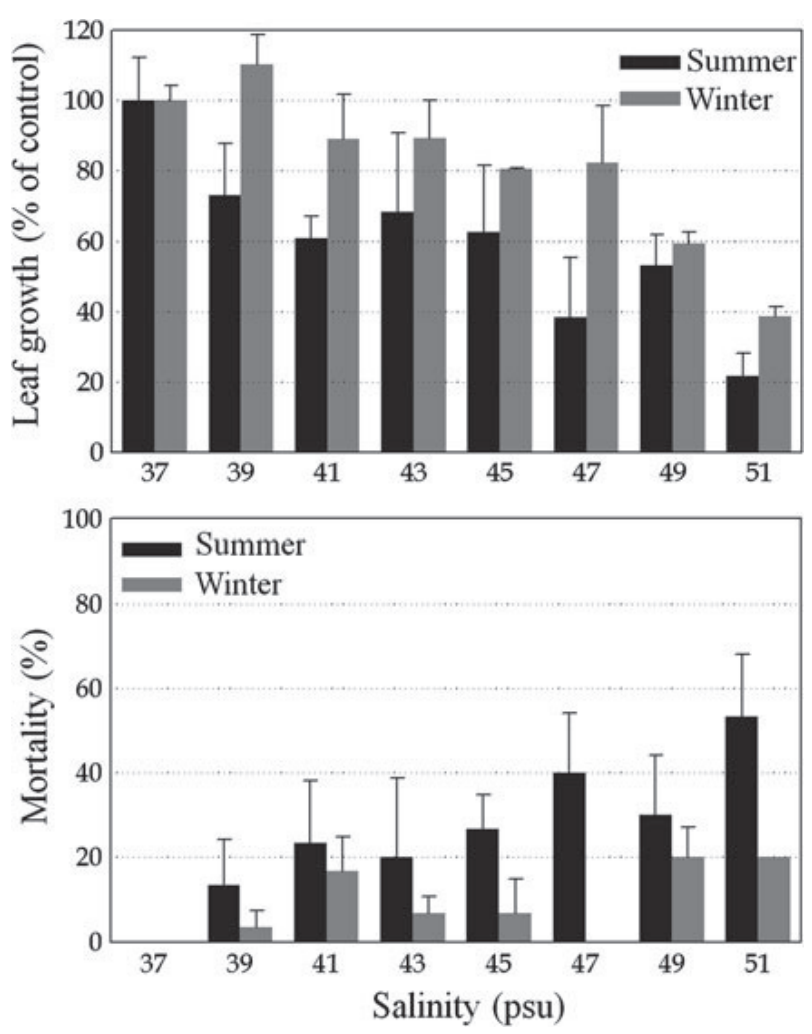

Fig. 3 Leaf growth per shoot, relative to the growth of the control plants, and mortality percentage of $C$. nodosa plants at different salinity levels during summer and winter (bars represent standard errors) lower $(\leq 20 \%)$ in winter, with higher mortality rates observed in summer (53.3\% at $51 \mathrm{psu})$.

ANOVA revealed a significant effect of the interaction between temperature and increased salinity on the leaf growth of this species $(P<0.01)$. Plants subjected to salinity levels between 37 and 48 psu showed greater shoot growth rates at the highest temperature $\left(25^{\circ} \mathrm{C}\right)$, but when salinity was increased to $53 \mathrm{psu}$, the increase in temperature did not affect leaf growth (Fig. 4). Although no interaction was found for mortality data (Table 1), mortalities associated with increases in salinity were lower at $25^{\circ} \mathrm{C}$ (Fig. 4). In fact, in this experiment, only salinity had a significant effect on the survival of $C$. nodosa shoots. Among the four salinity treatments, the highest mortality rates occurred at 53 psu (63.3-86.7\%), followed by 48 psu (20-40\%), with significantly lower values than 37 and 43 psu (3.3-6.7\%).

Analysis of variance also showed significant differences in the response to salinity among the populations studied (Table 1). Individuals from the Mar Menor presented greater shoot growth and survival rates than those from the Mediterranean Sea (Fig. 5). Similar shoot growth and survival was observed in plants subjected from 37 to 47 psu, with significantly lower values reported at $50 \mathrm{psu}$. On the other hand, although no significant interaction was observed, plants from the Mediterranean Sea exposed to 50 psu clearly showed lower growth and survival rates than those from the Mar Menor at the same salinity treatment (Fig. 5).

On the other hand, $C$. nodosa shoots acclimated to gradual increases in salinity ( 2.5 psu per day) showed higher shoot growth rates at the four salinity treatments studied than those not subjected to acclimation (Fig. 6). No dead shoots were found at the control salinity level. However, at high salinity levels, the mortality rate was higher for plants exposed to abrupt salinity changes, although ANOVA did not detect any significant interaction.

\section{Discussion}

Effects of salinity on shoot growth rate and survival of $C$. nodosa and Z. noltii

Under these laboratory conditions, Zostera noltii was found to be more tolerant of conditions of hyposalinity than Cymodocea nodosa, but both species were

\begin{tabular}{l|lll|} 
Journal : Medium 10750 & Dispatch : 25-3-2011 & Pages : 13 \\
Article No. : 644 & $\square$ LE & $\square$ TYPESET \\
MS Code : HYDR5743 & $\checkmark$ CP & $\checkmark$ DISK \\
\hline
\end{tabular}


Table 1 Summary of the two-way ANOVAs testing the effects of different salinity treatments combined with other factors or conditions on $C$. nodosa shoot growth rate and shoot mortality

\begin{tabular}{|c|c|c|c|c|c|c|c|}
\hline \multirow[t]{2}{*}{ Experiment } & \multirow[t]{2}{*}{ Source of variation } & \multicolumn{3}{|c|}{ Leaf elongation } & \multicolumn{3}{|c|}{ Mortality } \\
\hline & & $d f$ & MS & $F$ & $d f$ & MS & $F$ \\
\hline \multirow[t]{5}{*}{ Exp. III } & Salinity & 7 & 0.0329 & $5.08 * * *$ & 7 & 723.81 & $3.66 * *$ \\
\hline & Season of year & 1 & 0.7594 & $117.47 * * *$ & 1 & $3,333.33$ & $16.84 * *$ \\
\hline & Salinity $\times$ season & 7 & 0.0179 & $2.77 *$ & 7 & 280.95 & $1.42^{\mathrm{ns}}$ \\
\hline & Aquaria (salinity $\times$ season) & 32 & 0.0065 & $2.31 * * *$ & 32 & 197.91 & \\
\hline & Residual & 432 & 0.0028 & & & & \\
\hline \multirow[t]{5}{*}{ Exp. IV } & Salinity & 3 & 0.0404 & $94.32 * * *$ & 3 & $6,700.00$ & $41.23 * * *$ \\
\hline & Temperature & 1 & 0.0318 & $74.24 * * *$ & 1 & 600.00 & $3.69^{\mathrm{ns}}$ \\
\hline & Salinity $\times$ temperature & 3 & 0.0031 & $7.16^{* *}$ & 3 & 277.78 & $1.71^{\mathrm{ns}}$ \\
\hline & Aquaria (salinity $\times$ temperature) & 16 & 0.0004 & $0.75^{\mathrm{ns}}$ & 16 & 162.50 & \\
\hline & Residual & 216 & 0.0006 & & & & \\
\hline \multirow[t]{5}{*}{ Exp. V } & Salinity & 3 & 0.0003 & $5.73 * *$ & 3 & $1,181.94$ & $5.56 * *$ \\
\hline & Population & 1 & 0.0010 & $21.75 * * *$ & 1 & $2,204.17$ & $10.37 * *$ \\
\hline & Salinity $\times$ population & 3 & 0.0001 & $1.32^{\mathrm{ns}}$ & 3 & 604.17 & $2.84^{\mathrm{ns}}$ \\
\hline & Aquaria (salinity $\times$ population) & 16 & 0.0000 & $1.41^{\mathrm{ns}}$ & 16 & 212.50 & \\
\hline & Residual & 216 & 0.0000 & & & & \\
\hline \multirow[t]{5}{*}{ Exp. VI } & Salinity & 3 & 0.0602 & $7.40 * *$ & 3 & $1,693.06$ & $8.13 * *$ \\
\hline & Acclimation & 1 & 0.0490 & $6.02 *$ & 1 & $2,204.17$ & $10.58 * *$ \\
\hline & Salinity $\times$ acclimation & 3 & 0.0060 & $0.73^{\mathrm{ns}}$ & 3 & 293.06 & $1.41^{\mathrm{ns}}$ \\
\hline & Aquaria (salinity $\times$ acclimation) & 16 & 0.0081 & $2.46^{* *}$ & 16 & 208.33 & \\
\hline & Residual & 216 & 0.0033 & & & & \\
\hline
\end{tabular}

ns non-significant, $* P<0.05$, ** $P<0.01$, *** $P<0.005$

441 sensitive to increases in salinity. These experiments 442 showed significant decreases in shoot growth rates in 443 both seagrasses at salinity levels higher than 41 psu. 444 A decrease in leaf growth was also observed at 445 salinity levels lower than 15 psu for Cymodocea 446 nodosa, whereas $Z$. noltii plants were found to be 447 highly tolerant to salinity levels as low as $2 \mathrm{psu}$, 448 which was the lowest salinity treatment tested for the 449 10-day period. This tolerance to low levels of salinity 450 has also been found for other seagrasses, such as 451 Amphibolis antarctica and Posidonia sinuosa, which 452 can be highly tolerant to short-term reductions in 453 salinity, even as low as 0-1 psu (Westphalen et al., 454 2005). The relationship between leaf growth and 455 salinity was well described by a bell-shaped curve for 456 C. nodosa, and by a sigmoid curve for $Z$. noltii, with 457 maximum values recorded around ambient salinity 458 levels. Similar responses, but with different relation459 ships between salinity and plant growth, have 460 been observed in several seagrasses (McMillan \& 461 Moseley, 1967; Walker, 1985; Walker \& McComb,
1990; Kamermans et al., 1999) probably due to adverse effects on the meristematic tissues, interferences with carbon metabolism or negative alterations in the photosynthetic and respiratory rates (Ogata \& Matsui, 1965; Biebl \& McRoy, 1971; Kraemer et al., 1999).

Mortality values for $C$. nodosa were significantly lower for salinity levels between 17 and 48 psu, with all plants dying at salinity levels of more than 56 psu. For Z. noltii, mortality was significantly lower at salinity levels below 47 psu, with $100 \%$ mortality at salinity levels above 56 psu. Previous studies have confirmed that salinity variations may affect seagrass survival under experimental conditions (Biebl \& McRoy, 1971; Pinnerup, 1980; Vermaat et al., 2000; Fernández-Torquemada \& Sánchez-Lizaso, 2005; Fernández-Torquemada et al., 2005b), as well as in their natural habitats (Robblee et al., 1991; Wortmann et al., 1997; Kamermans et al., 1999; van Katwijk et al., 1999). Water salinities outside the tolerance range of a species may alter its metabolism and therefore cause direct death of the plant at very

\begin{tabular}{|l|lll|}
\hline & Journal : Medium 10750 & Dispatch : 25-3-2011 & Pages : 13 \\
Article No. : 644 & $\square$ LE & $\square$ TYPESET \\
MS Code : HYDR5743 & $\checkmark$ CP & $\checkmark$ DISK \\
\hline
\end{tabular}



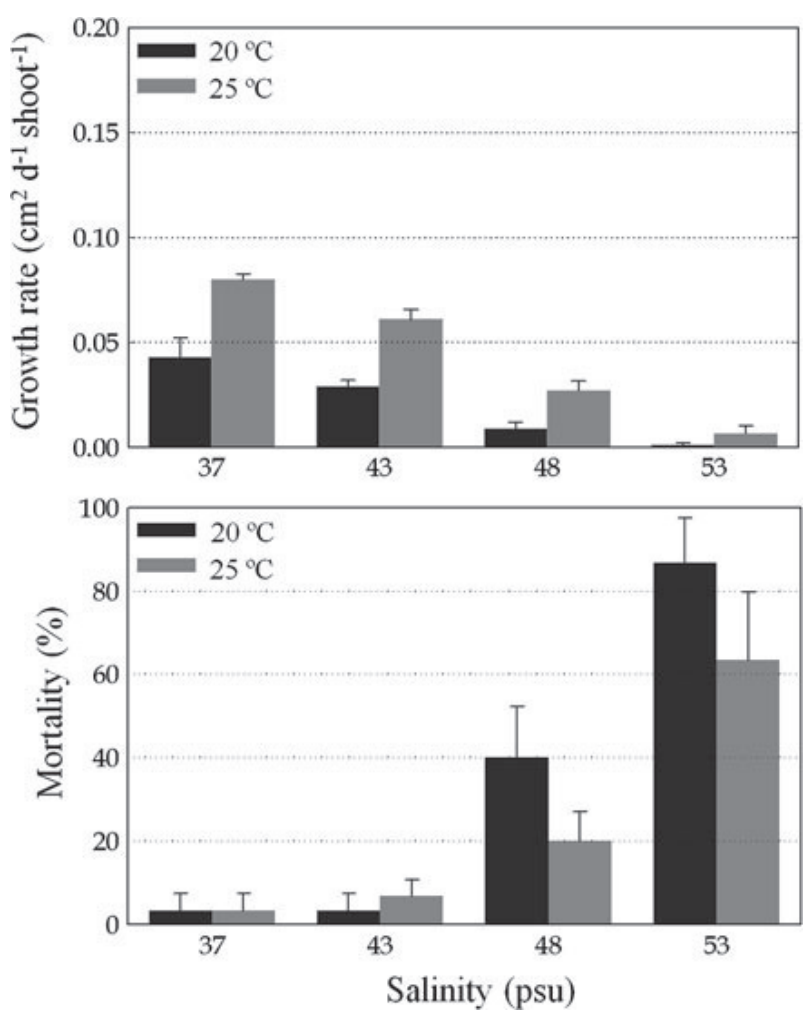

Fig. 4 Cymodocea nodosa shoot growth rate $\left(\mathrm{cm}^{2}\right.$ day ${ }^{-1}$ shoot $^{-1}$ ) and shoot mortality (\%) at different salinity levels and temperatures (bars represent standard errors)

extreme levels (McMillan \& Moseley, 1967; Adams $\&$ Bates, 1994), or death in the long term if causing starch-reserve depletion (Biebl \& McRoy, 1971; Kerr \& Strother, 1985).

These results are also in accordance with the field distribution of both seagrasses. Z. noltii is known to colonise estuary and delta areas with a higher influence of freshwater inputs than $C$. nodosa (Vermaat et al., 2000; Greve \& Binzer, 2004). Our data are also coherent with the known colonisation of these species in the Mar Menor, a coastal lagoon located in the southeast of Spain. Until the end of the nineteenth century, this lagoon contained very high salinity levels (60-70 psu) that prevented it being colonised by macrophytes. However, a subsequent connection was established between the lagoon and the Mediterranean Sea, causing salinity to drop to the current levels (42-47 psu), allowing for the existing seagrass meadows to become established (Pérez Ruzafa et al., 1987).

It should be emphasised that all these experiments were carried out under controlled aquarium conditions and in short periods of time (10 days), so the response
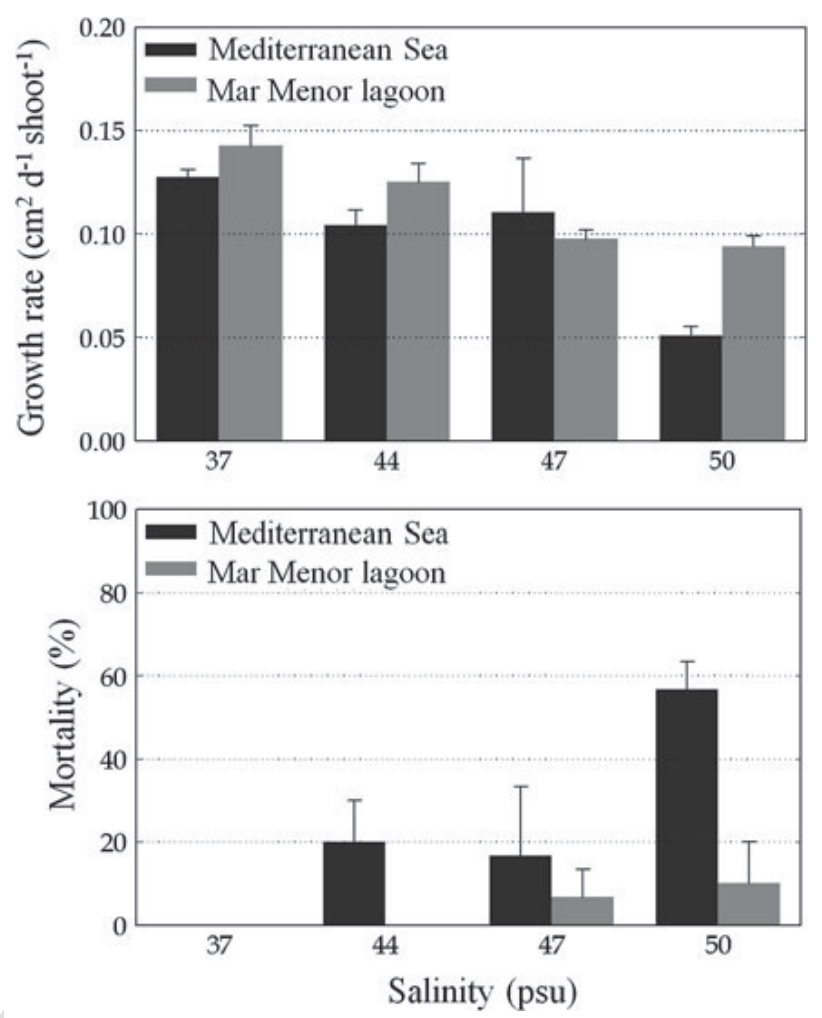

Fig. 5 Shoot growth rate $\left(\mathrm{cm}^{2}\right.$ day $^{-1}$ shoot $\left.^{-1}\right)$ and mortality percentage of $C$. nodosa plants from two different populations exposed to different salinity levels (bars represent standard errors)

observed here could differ to the one observed in the natural environment. However, Walker \& McComb (1990) compared the effect of salinity variations on the growth of a tropical seagrass, both in situ and in aquaria, and found that its tolerance was similar in both cases. In the present study, aquaria experiments were also performed under low light levels $(30 \mu \mathrm{mol}$ quanta $\mathrm{m}^{-2} \mathrm{~s}^{-1}$ ), but higher environmental light levels could imply a lower mortality or higher growth of plants under stressing salinity treatments, because those plants could be subjected to an additional costressor, the low light level. Moreover, we only worked with growth and survival of those species, and no information about photosynthesis or other descriptors is given. On the other hand, this study focussed solely on the effects of increases in salinity on the growth and survival of adult shoots, and the sensitivity to environmental variations may differ considerably between seedlings and adult plants, with young stages typically being more sensitive to stressors than adult ones. Future studies should therefore investigate the effects of increases in salinity, together with

\begin{tabular}{|l|ll|} 
Journal : Medium 10750 & Dispatch : 25-3-2011 & Pages : 13 \\
Article No. : $\mathbf{6 4 4}$ & $\square$ LE & $\square$ TYPESET \\
MS Code : HYDR5743 & $\checkmark$ CP & $\checkmark$ DISK \\
\hline
\end{tabular}



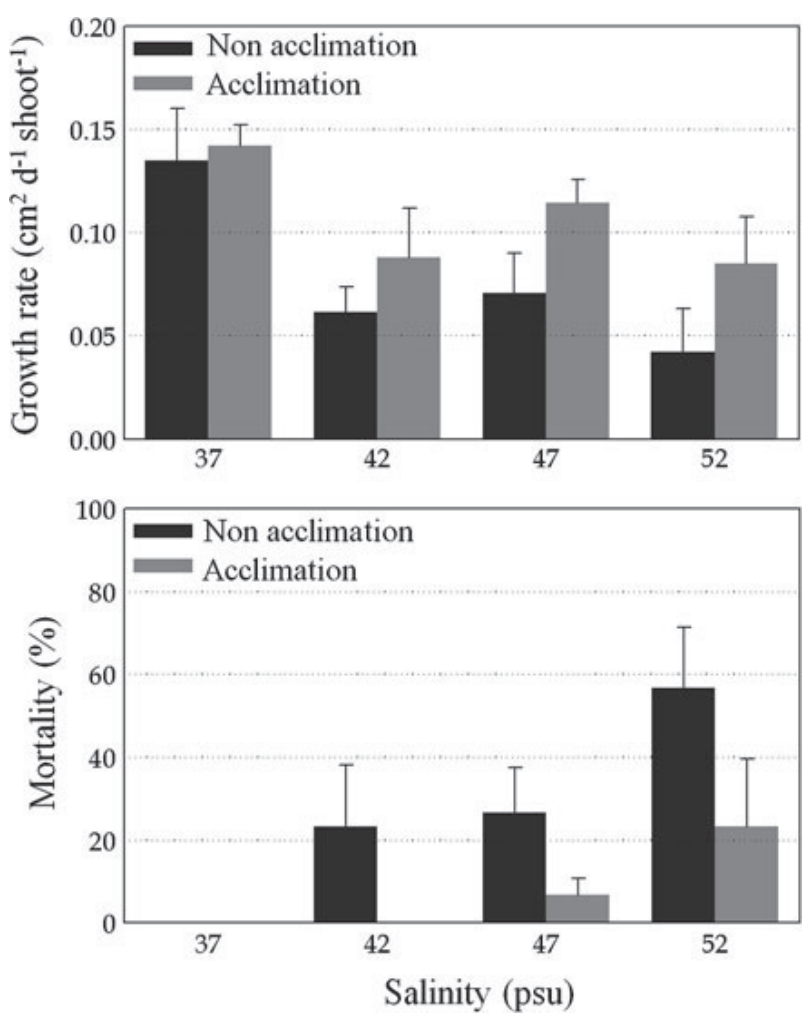

Fig. 6 Shoot growth rate $\left(\mathrm{cm}^{2}\right.$ day $^{-1}$ shoot $\left.^{-1}\right)$ and shoot mortality (\%) of $C$. nodosa plants acclimated to salinity increases $\left(2.5 \mathrm{psu} \mathrm{day}^{-1}\right)$ versus plants subjected to sudden salinity increases (bars represent standard errors) variations in other conditions, on seedling development and seed germination of these species.

Nevertheless, if we compare the results obtained here for $C$. nodosa and Z. noltii with those obtained for P. oceanica (Fernández-Torquemada \& SánchezLizaso, 2005), it can be observed that these species were able to tolerate a wider range of salinity levels than $P$. oceanica. This is coherent with the fact that C. nodosa and Z. noltii are smaller and much more plastic species, with a higher capacity to adapt to environmental changes and recover from slight disturbances (Pérez et al., 1994; Kraemer \& Mazzella, 1999).

Interactions of salinity with other factors on Cymodocea nodosa

Previous experiments have demonstrated the sensitivity of $C$. nodosa to salinity variations in the short term (10 days), but tolerance to salinity may also depend on other environmental or intra-specific factors. Other studies have demonstrated that osmotic stress could modify the sensitivity of some seagrasses to other environmental conditions, such as temperature or $\mathrm{pH}$ increases, light levels or eutrophication (Biebl \& McRoy, 1971; Ralph 1999; van Katwijk et al., 1999; Vermaat et al., 2000).

Mediterranean seawater temperatures vary considerably between seasons, but rapid temperature increases may be linked to brine discharges from certain desalination plants. For example, brine discharges from multi-stage flash desalination plants can cause increases of $15^{\circ} \mathrm{C}$ in the seawater temperature in the receiving environment (Lattemann \& Höpner, 2003). On the other hand, brine discharges from reverse osmosis desalination plants do not imply temperature increases, though it has been observed that, in some of these facilities and during certain periods of the year, the temperature of the effluent can produce a slight increase in that of the receiving environment (Fernández-Torquemada et al., 2005a).

Temperature is considered an important abiotic factor that controls the production, growth and survival of a species (Drew, 1979), and it has been demonstrated that its influence on the metabolism of marine plants modifies their capacity to adapt to changes in other environmental factors, such as illumination or salinity (Zieman, 1975). Plant growth is most affected by light and temperature (Philippart, 1995; Marbà et al., 1996), and when these parameters are close to a species' optimum values, this species will tolerate a broader range of salinity levels (Kirst, 1989). It is known that, in several species of algae, such as Macrocystis integrifolia, Alaria esculenta and Cladophora rupestris, tolerance to saline stress is reduced at extreme levels within their temperature tolerance range (Druehl, 1981; Dring, 1992; Thomas et al., 1988). In seagrasses, Biebl \& McRoy (1971) found an increase in plasmatic heat resistance with increasing levels of salinity for subtidal forms of Zostera marina, and Vermaat et al. (2000) observed increased mortality in $Z$. noltii when the temperature reached $20^{\circ} \mathrm{C}$ at higher experimental levels of salinity. Thorhaug \& Marcus (1981) indicated that four seagrass species were less tolerant of low salinity levels at temperature above $29^{\circ} \mathrm{C}$. The present work has also observed a significant interaction between the two factors. For salinities ranging from 37 to 48 psu, $C$. nodosa plants possessed a higher growth rate at the highest temperature $\left(25^{\circ} \mathrm{C}\right)$, but when the

\begin{tabular}{|l|lll|}
\hline & Journal : Medium 10750 & Dispatch : 25-3-2011 & Pages : 13 \\
Article No. : $\mathbf{6 4 4}$ & $\square$ LE & $\square$ TYPESET \\
MS Code : HYDR5743 & $\vee_{\mathrm{CP}}$ & $\checkmark$ DISK \\
\hline
\end{tabular}


salinity was increased to $53 \mathrm{psu}$, the increase in temperature did not have a positive effect on leaf growth. This is probably because the increase in metabolic activity at high temperatures is insufficient for coping with the stress caused by high salinity levels.

Cymodocea nodosa is also affected by seasonality, showing minimum growth in winter due to lower irradiance and temperatures. In this study, it was observed that the salinity tolerance range of this species may also vary throughout the year. This could be related to maximum growth and, therefore, the higher energy and metabolic consumption that occur in summer due to the species' life cycle that makes more evident salinity effects. In winter, plants survive with smaller metabolic levels and are more able to resist salinity-related stress.

On the other hand, tolerance can differ considerably at one level of salinity depending on how such a level is reached. Other studies report that gradual increases in salinity are usually better resisted than a sudden or rapid rise (Ralph, 1998). In this study, C. nodosa plants exposed to slower increases of salinity (2.5 psu per day) were able to tolerate changes in salinity better than plants that had not been acclimated, showing higher rates of growth and survival.

The capacity of $C$. nodosa to improve its tolerance to slow increases in salinity can be explained by an acclimation of plants, and some structural or physiological reversible changes that occur when plants are exposed to stress. But when studying other stresses, it has been observed that some plant populations exposed to these same conditions during a longer period may be able to adapt by means of some genetic and irreversible changes (Peralta et al., 2005).

In fact, when conducting one of the experiments comparing the response of Cymodocea nodosa plants from the Mar Menor lagoon with plants from the Alicante (Mediterranean) near-shore coast, different behaviours to salinity variations were observed for both populations. For the Mediterranean population studied, salinity tolerance was narrower than for the Mar Menor population, as indicated by the high rates of mortality and the significant reduction in shoot growth rate at 50 psu. Plants from the Mar Menor, meanwhile, showed a lower sensitivity to increases in salinity, and similar rates of mortality and leaf growth inside the salinity range studied. Salinity in the Mar Menor lagoon currently ranges between 42 and 47 psu, and western Mediterranean coasts are at levels of $\sim 37$ and 38 psu. So these differences in tolerance to salinity could be explained because, as occurs with other widespread species, individuals adapt to the different local conditions that occur naturally in their habitats (Doering \& Chamberlain, 1998; Benjamin et al., 1999; Kamermans et al., 1999; van Katwijk et al., 1999; Vermaat et al., 2000). For example, Kamermans et al. (1999) and van Katwijk studies performed with $C$. nodosa, significant differences have also been found in the behaviour of the seeds of this species in populations from the Golfe Juan Bay in the French Mediterranean (Caye et al., 1992) and from the Island of Ischia in Naples (Pirc et al., 1986), although these differences were attributed to the genetic variability of this species inside the Mediterranean Sea. Consequently, it may be possible that the wide geographical distribution of a species could imply different tolerances among its populations.

Acknowledgements This research was financed by an ACUAMED contract and by an FPI grant (FPI 01 A 002) from the Generalitat Valenciana.

\section{References}

Adams, J. B. \& G. C. Bate, 1994. The ecological implications of tolerance to salinity by Ruppia cirrhosa (Petagna) Grande and Zostera capensis Setchell. Botanica Marina 37: 449-456.

Arai, M., J. Y. Pak, K. Nomura \& T. Nitta, 1991. Seawaterresistant, non-spherical protoplasts from seagrass leaves. Physiologia Plantarum 83: 551-559.

Benjamin, K. J., D. I. Walker, A. J. McComb \& J. Kuo, 1999. Structural response of marine and estuarine plants of Halophila ovalis (R.Br.) Hook. $f$. to long-term hyposalinity. Aquatic Botany 64: 1-17.

Biebl, R. \& C. P. McRoy, 1971. Plasmatic resistance of respiration and photosynthesis of Zostera marina at different salinities and temperatures. Marine Biology 8: 48-56.

Caye, G. \& A. Meinesz, 1986. Experimental study of seed germination in the seagrass Cymodocea nodosa. Aquatic Botany 26: 79-87.

Caye, G., C. Bulard, A. Meinesz \& F. Loquès, 1992. Dominant role of seawater osmotic pressure on germination in Cymodocea nodosa. Aquatic Botany 42: 187-193.

Charpentier, A., P. Grillas, F. Lescuyer, E. Coulet \& I. Auby, 2005. Spatio-temporal dynamics of a Zostera noltii dominated community over a period of fluctuating salinity in a shallow lagoon, Southern France. Estuarine Coastal and Shelf Science 64: 307-315.
670

671

672

673

674

675

676

677

678

679

680

681

682

683

684

685

686

687

688

689

690

691

692

693

694

\begin{tabular}{|l|ll|} 
Journal : Medium 10750 & Dispatch : 25-3-2011 & Pages : 13 \\
Article No. : $\mathbf{6 4 4}$ & $\square$ LE & $\square$ TYPESET \\
MS Code : HYDR5743 & $\sim_{\text {CP }}$ & $\checkmark$ DISK \\
\hline
\end{tabular}


Chesnes, T. C. \& C. L. Montague, 2001. The effects of salinity fluctuation on the productivity and osmoregulation of two seagrass species. Estuarine Research Federation Conference Abstracts, November 4-8, 2001, St. Petersburg, Florida.

den Hartog, C., 1970. The Sea-Grasses of the World. NorthHolland Publications Company, Amsterdam.

Doering, P. H. \& R. H. Chamberlain, 1998. Experimental studies on the salinity tolerance of turtle grass, Thalassia testudinum. In Bortone, S. A. (ed.), Workshop on Seagrasses. Subtropical and Tropical Seagrass Management Ecology: Responses to Environmental Stress. Fort Myers, Florida: 13.

Drew, E. A., 1978. Factors affecting photosynthesis and its seasonal variation in the seagrasses Cymodocea nodosa (Ucria) Ascherson and Posidonia oceanica (L.) Delile in the Mediterranean. Journal of Experimental Marine Biology and Ecology 31: 173-194.

Drew, E. A., 1979. Physiological aspects of primary production in seagrasses. Aquatic Botany 7: 139-150.

Dring, M. J., 1992. The Biology of Marine Plants. Cambridge University Press, Cambridge.

Druehl, L. D., 1981. Geographical distribution. In Lobban, L. S. \& M. J. Wynne (eds), The Biology of Seaweeds. Blackwell, Oxford: 306-325.

Fernández, J. A., M. J. García-Sánchez \& H. H. Felle, 1999. Physiological evidence for a proton pump and sodium exclusion mechanisms at the plasma membrane of the marine angiosperm Zostera marina L. Journal of Experimental Botany 50: 1763-1768.

Fernández-Torquemada, Y. \& J. L. Sánchez-Lizaso, 2005. Effects of salinity on leaf growth and survival of the Mediterranean seagrass Posidonia oceanica (L.) Delile. Journal of Experimental Marine Biology and Ecology 320: 57-63.

Fernández-Torquemada, Y., J. M. González-Correa \& J. L. Sánchez-Lizaso, 2005a. Preliminary results of the monitoring of the brine discharge produced by the SWRO desalination plant of Alicante (SE Spain). Desalination 182: 395-402.

Fernández-Torquemada, Y., M. J. Durako \& J. L. SánchezLizaso, 2005b. Effects of salinity and possible interactions with temperature and $\mathrm{pH}$ on growth and photosynthesis of Halophila johnsonii Eiseman. Marine Biology 148: 251-260.

Fernández-Torquemada, Y., J. M. Gónzalez-Correa, A. Loya, L. M. Ferrero, M. Díaz-Valdés \& J. L. Sánchez-Lizaso, 2009. Dispersion of brine discharge from seawater reverse osmosis desalination plants. Desalination and Water Treatment 5: 137-145.

Fukuhara, T., J. Y. Pak, Y. Ohwaki, H. Tsujimura \& T. Nitta, 1996. Tissue-specific expression of the gene for a putative plasma membrane $\mathrm{H}^{+}$-ATPase in a seagrass. Plant Physiology 110: 35-42.

Gacia, E., O. Invers, M. Manzanera, E. Ballesteros \& J. Romero, 2007. Impact of the brine from a desalination plant on a shallow seagrass (Posidonia oceanica) meadow. Estuarine Coastal and Shelf Science 72: 579-590.

Greve, T. M. \& T. Binzer, 2004. Which factors regulate seagrass growth and distribution? In Borum, J., C. M. Duarte, D. Krause-Jensen \& T. M. Greve (eds), European
Seagrasses an Introduction to Monitoring and Management. The M\&Ms Project, Hillerød: 19-23.

Hillman, K., A. J. McComb \& D. I. Walker, 1995. The distribution, biomass and primary production of the seagrass Halophila ovalis in the Swan/Canning Estuary, Western Australia. Aquatic Botany 51: 1-54.

Hootsmans, M. J. M., J. E. Vermaat \& W. van Vierssen, 1987. Seed bank development, germination and early seedling survival of two seagrass species from The Netherlands: Zostera marina L. and Zostera noltti Hornem. Aquatic Botany 28: 275-285.

Jagels, R., 1973. Studies of a marine grass, Thalassia testudinum I. Ultrastructure of the osmoregulatory leaf cells. American Journal of Botany 60: 1003-1009.

Kamermans, P., M. A. Hemminga \& D. J. de Jong, 1999. Significance of salinity and silicon levels for growth of a formerly estuarine eelgrass (Zostera marina) population (Lake Grevelingen, The Netherlands). Marine Biology 133: 527-539.

Kerr, E. A. \& S. Strother, 1985. Effects of irradiance, temperature and salinity on photosynthesis of Zostera mиelleri. Aquatic Botany 23: 177-183.

Kinne, O., 1964. The effects of temperature and salinity on marine and brackish water animals. II. Salinity and temperature salinity combinations. In Barnes, H. (ed.), Oceanography and Marine Biology. An Annual Review. Haefner, New York: 281-339.

Kirst, G. O., 1989. Salinity tolerance of eukaryotic marine algae. Annual Reviews of Plant Physiology. Plant Molecular Biology 40: 21-53.

Kraemer, G. \& L. Mazzella, 1999. Nitrogen acquisition, storage, and use by the co-occurring Mediterranean seagrasses Cymodocea nodosa and Zostera noltii. Marine Ecology Progress Series 183: 95-103.

Kraemer, G., R. H. Chamberlain, P. H. Doering, A. D. Steinman \& M. Hanisak, 1999. Physiological responses of transplant of the freshwater angiosperm Vallisneria americana along a salinity gradient in the Caloosahatchee Estuary (Southwestern Florida). Estuaries 22: 138-148.

Lattemann, S. \& T. Höpner, 2003. Seawater desalination. Impacts of brine and chemical discharges on the marine environment, Desalination Publications, L'Aquila.

Loques, F., G. Caye \& A. Meinesz, 1990. Germination in the marine phanerogam Zostera noltii Hornemann at Golfe Juan, French Mediterranean. Aquatic Botany 38: 249-260.

Marbà, N., J. Cebrian, S. Enríquez \& C. M. Duarte, 1996. Growth patterns of Western Mediterranean seagrasses: species-specific responses to seasonal forcing. Marine Ecology Progress Series 133: 203-215.

Mazzella, L., M. B. Scipione, M. C. Gambi, M. C. Buia, M. Lorenti, V. Zupo \& G. Cancemi, 1993. The Mediterranean seagrass Posidonia oceanica and Cymodocea nodosa. A comparative overview. First International Conference on the Mediterranean Coastal Environment, Antalya, Turkey: 103-116.

McMillan, C. \& F. N. Moseley, 1967. Salinity tolerances of five marine spermatophytes of Redfish Bay, Texas. Ecology 48: 503-506.

Montague, C. L. \& J. A. Ley, 1993. A possible effect of salinity fluctuation on abundance of benthic vegetation and

\begin{tabular}{|l|ll|} 
Journal : Medium 10750 & Dispatch : 25-3-2011 & Pages : 13 \\
Article No. : $\mathbf{6 4 4}$ & $\square$ LE & $\square$ TYPESET \\
MS Code : HYDR5743 & $\checkmark$ CP & DISK \\
\hline
\end{tabular}


associated fauna in Northeastern Florida Bay. Estuaries 16: 703-717.

Ogata, E. \& T. Matsui, 1965. Photosynthesis in several marine plants of Japan as affected by salinity, drying and $\mathrm{pH}$, with attention to their growth habitats. Botanica Marina 8: 199-217.

Pagès, J. F., M. Pérez \& J. Romero, 2010. Sensitivity of the seagrass Cymodocea nodosa to hypersaline conditions: a microcosm approach. Journal of Experimental Marine Biology and Ecology 386: 34-38.

Pak, J. Y., T. Fukuhara \& T. Nitta, 1995. Discrete subcellular localization of membrane-bound ATPase activity in marine angiosperms and marine algae. Planta 196: 15-22.

Pavón-Salas, N., R. Herrera, A. Hernández-Guerra \& R. Haroun, 2000. Distributional pattern of seagrasses in the Canary Islands (Central-East Atlantic Ocean). Journal of Coastal Research 16: 328-335.

Peduzzi, P. \& A. Vukovič, 1990. Primary production of Cymodocea nodosa in the Gulf of Trieste (northern Adriatic Sea): a comparison of methods. Marine Ecology Progress Series 64: 197-207.

Peralta, G., F. G. Brun, I. Hernández, J. J. Vergara \& J. L. Pérez-Lloréns, 2005. Morphometric variations as acclimation mechanisms in Zostera noltii beds. Estuarine Coastal and Shelf Science 64: 347-356.

Pérez, M. \& J. Romero, 1992. Photosynthetic response to light and temperature of the seagrass Cymodocea nodosa and the prediction of its seasonality. Aquatic Botany 43: 51-62.

Pérez, M., C. M. Duarte, J. Romero, K. Sand-Jensen \& T. Alcoverro, 1994. Growth plasticity in Cymodocea nodosa stands: the importance of nutrient supply. Aquatic Botany 47: 249-264.

Pérez Ruzafa, A., C. Marcos, I. M. Pérez Ruzafa \& J. D. Ros, 1987. Evolución de las características ambientales y de los doblamientos del Mar Menor (Murcia, SE España). Anales de Biología 12: 53-65.

Philippart, C. J. M., 1995. Seasonal variation in growth and biomass of an intertidal Zostera noltii stand in the Dutch Wadden Sea. Netherlands Journal of Sea Research 33: 205-218.

Phillips, R. C. \& E. G. Meñez, 1988. Seagrasses. Smithsonian Institution Press, Washington.

Pinnerup, S. P., 1980. Leaf production of Zostera marina L. at different salinities. Ophelia Supplement 1: 219-224.

Pirc, H., M. C. Buia \& L. Mazzella, 1986. Germination and seedling development of Cymodocea nodosa (Ucria) Ascherson under laboratory conditions and "in situ". Aquatic Botany 26: 181-188.

Ralph, P. J., 1998. Photosynthetic responses of Halophila ovalis (R. Br.) Hook. f. to osmotic stress. Journal of Experimental Marine Biology and Ecology 227: 203-220.

Ralph, P. J., 1999. Photosynthetic response of Halophila ovalis (R.Br.) Hook. $f$. to combined environmental stress. Aquatic Botany 65: 83-96.

Ramage, D. L. \& D. R. Schiel, 1998. Reproduction in the seagrass Zostera novazelandica on intertidal platforms in southern New Zealand. Marine Biology 130: 479-489.

Reyes, J., M. Sansón \& J. Afonso-Carrillo, 1995. Distribution and reproductive phenology of the seagrass Cymodocea nodosa (Ucria) Ascherson in the Canary Islands. Aquatic Botany 50: 171-180.

Robblee, M. B., T. R. Barber, P. R. Carlson, M. J. Durako, J. W. Fourqurean, L. K. Muehlstein, D. Porter, L. A. Yarbro, R. T. Zieman \& J. C. Zieman, 1991. Mass mortality of the tropical seagrass Thalassia testudinum in Florida Bay (USA). Marine Ecology Progress Series 71: 297-299.

Sánchez-Lizaso, J. L., J. Romero, J. Ruiz, E. Gacia, J. L. Buceta, O. Invers, Y. Fernández-Torquemada, J. Mas, A. Ruiz-Mateo \& M. Manzanera, 2008. Salinity tolerance of the Mediterranean seagrass Posidonia oceanica: recommendations to minimize the impact of brine discharges from desalination plants. Desalination 221: 602-607.

Thomas, D. N., J. C. Collins \& G. Russell, 1988. Interactive effects of temperature and salinity upon net photosynthesis of Cladophora glomerata (L.) Kütz. and C. rupestris (L.) Kütz. Botanica Marina 31: 73-77.

Thorhaug, A. \& J. Marcus, 1981. Mortality of Thalassia testudinum (Banks ex Konig) when exposed to the extremes of temperature, salinity and light. American Journal of Botany 68: 1102.

Tomasko, D. A. \& M. O. Hall, 1999. Productivity and biomass of the seagrass Thalassia testudinum along a gradient of freshwater influence in Charlotte Harbor, Florida. Estuaries 22: 592-602.

Touchette, B. W., 2007. Seagrass-salinity interactions: physiological mechanisms used by submersed marine angiosperms for a life at sea. Journal of Experimental Marine Biology and Ecology 350: 194-215.

Tyerman, S. D., 1989. Solute and water relations of seagrasses. In Larkum, A. W. D., A. J. McComb \& S. A. Shepherd (eds), Biology of Seagrasses. Elsevier, Amsterdam: 729-759.

Underwood, A. J., 1997. Experiments in Ecology. Their Logical Design and Interpretation using Analysis of Variance. Cambridge University Press, Cambridge.

Underwood, A. J. \& M. G. Chapman. 1997. Statistical program GMAV.5 for Windows. Institute of Marine Ecology, University of Sidney, Australia.

van Katwijk, M. M., G. H. W. Schmitz, A. P. Gasseling \& P. H. van Avesaath, 1999. Effects of salinity and nutrient load and their interaction on Zostera marina. Marine Ecology Progress Series 190: 155-165.

Vermaat, J. E., J. A. J. Beijer, R. Gijlstra, M. J. M. Hootsmans, C. J. M. Philippart, N. W. van den Brink \& W. van Vierssen, 1993. Leaf dynamics and standing stocks of intertidal Zostera noltii Hornem and Cymodocea nodosa (Ucria) Ascherson on the Banc d'Arguin (Mauritania). Hydrobiologia 258: 59-72.

Vermaat, J. E., F. C. A. Verhagen \& D. Lindenburg, 2000. Contrasting responses in two populations of Zostera noltii Hornem. to experimental photoperiod manipulation at two salinities. Aquatic Botany 67: 179-189.

Walker, D. I., 1985. Correlations between salinity and growth of the seagrass Amphibolis antarctica (Labill.) Sonder \& Aschers., in Shark Bay, Western Australia, using a new method for measuring production rate. Aquatic Botany 23: 13-26.

Walker, D. I. \& A. J. McComb, 1990. Salinity response of the seagrass Amphibolis antarctica (Labill.) Sonder et

\begin{tabular}{|lll|} 
Journal : Medium 10750 & Dispatch : 25-3-2011 & Pages : 13 \\
Article No. : 644 & $\square$ LE & $\square$ TYPESET \\
MS Code : HYDR5743 & $\checkmark$ CP & $\checkmark$ DISK \\
\hline
\end{tabular}


Aschers.: an experimental validation of field results. Aquatic Botany 36: 359-366.

Westphalen, G., E. O'Loughlin, G. Collings, J. Tanner, Y. Eglinton \& S. Bryars, 2005. Responses to reduced salinities of the meadow forming seagrasses Amphibolis and Posidonia from the Adelaide metropolitan coast. ACWS technical report no 9 prepared for the Adelaide Coastal Waters Study Steering Committee. South Australian Research and Development Institute (Aquatic Sciences) Publication No. RD01/020814, Adelaide. http://www.epa. sa.gov.au/pdfs/acws9.pdf.
Wortmann, J., J. W. Hearne \& J. B. Adams, 1997. A mathematical model of an estuarine seagrass. Ecological Modeling 98: 137-149.

Zieman, J. C., 1974. Methods for the study of the growth and production of turtle grass, Thalassia testudinum König. Aquaculture 4: 139-143.

Zieman, J. C., 1975. Seasonal variation of turtle grass, Thalassia testudinum König, with reference to temperature and salinity effects. Aquatic Botany 1: 107-123.

\begin{tabular}{|lll|} 
Journal : Medium 10750 & Dispatch : 25-3-2011 & Pages : 13 \\
Article No. : $\mathbf{6 4 4}$ & $\square$ LE & $\square$ TYPESET \\
MS Code : HYDR5743 & $\sim_{\mathrm{CP}}$ & $\checkmark$ DISK \\
\hline
\end{tabular}

